\title{
The use of Usability Tests in Website-Based Student Report Value Processing Information Systems
}

\author{
Arip Solehudin ${ }^{1}$ \\ Technical Information \\ Faculty of Computer Science, \\ University Singaperbangsa \\ Karawang, Indonesia \\ arip.solehudin@staff.unsika.ac.id
}

\author{
Nono Heryana ${ }^{2}$ \\ Information System \\ Faculty of Computer Science, \\ University Singaperbangsa \\ Karawang, Indonesia \\ nono@unsika.ac.id
}

\author{
Rieke Retnosary ${ }^{3}$ \\ Information System \\ Faculty of Computer Science, \\ University Buana Perjuangan \\ Karawang, Indonesia \\ riekeretnosary@ubpkarawang.ac.id
}

\begin{abstract}
The information system for processing student report cards based on the website is a system that provides information on student activity reports online in the form of grade reports and related student information based on the web, thus helping speed and quality in delivering information. Problems that occur in processing report cards at SMPN 2 Telagasari are currently still using report cards and inputting student scores is still manual. This study aims to build a value information system that makes it easier to check, record, and report computerized student grade data. In addition, by being web-based, data information can be accessed at any time. This website uses XAMPP as a web server for system design and MySQL as a database. The design of the login menu consisting of admins, teachers, and students has separate access when opening the application so that the security of the program is maintained. Testing this website using black-box testing and Likert scale usability testing to make it easier for authors to assess whether this online report card processing information system website can facilitate users.
\end{abstract}

Keywords: Information System, Value, Report Card, Website, MySQL

Abstrak - Sistem informasi pengolahan raport siswa berbasis website merupakan sistem yang menyediakan informasi laporan kegiatan siswa secara online berupa raport nilai dan informasi siswa terkait berbasis web, sehingga membantu kecepatan dan kualitas dalam penyampaian informasi. Permasalahan yang terjadi dalam pengolahan raport di SMPN 2 Telagasari saat ini masih menggunakan raport dan penginputan nilai siswa masih manual. Penelitian ini bertujuan untuk membangun sistem informasi nilai yang memudahkan pengecekan, pencatatan, dan pelaporan data nilai siswa secara komputerisasi. Selain itu, dengan berbasis web, informasi data dapat diakses setiap saat. Website ini menggunakan XAMPP sebagai web server untuk perancangan sistem dan MySQL sebagai database. Perancangan menu login yang terdiri dari admin, guru, dan siswa memiliki akses tersendiri saat membuka aplikasi sehingga keamanan program tetap terjaga. Pengujian website ini menggunakan pengujian black box dan pengujian usability skala likert untuk memudahkan penulis menilai apakah website sistem informasi pengolahan raport online ini dapat memudahkan pengguna.

Kata kunci: Sistem Informasi, Nilai, Rapor, Website, MySQL

\section{PRELIMINARY}

The use of technology and information is now also an aspect of life that is not only limited to the work environment. This is what makes technology and data very important for the survival of society. School is an environment that has used information technology.

Education is an institution that aims to provide services in the academic aspect that is used by many people in guiding a student. The school directs students to become people who can advance the nation. The school is one of the bodies devoted to guiding students in the monitoring of educators.

At the end of each semester, the school evaluates a student in one semester as a basis for measuring academic progress that has been passed. Each teacher will process these values and then will be given to each homeroom teacher respectively. Each homeroom teacher then collects and produces in one form an evaluation document, which results in a document known as a student report card.

The processing of report cards at SMP Negeri 2 Telagasari is arguably less efficient and not optimal. Each subject teacher gives grades to students which are then handed over to the homeroom teacher to be processed into a diploma (report). In the process of ensuring the student report card numbers continue to use the old method. Subject teachers share student grades with homeroom teachers using excel separately. This makes it difficult for the homeroom teacher to rework the information submitted by the teacher on the subject, as a result, the way the report card works is held back for each grade. The software used does not match the wishes of consumers as a result, it causes consumers to have difficulty in working on student report cards. This of course causes the process of processing information and making information, from the processing field not so optimal, it can limit the way of searching and presenting the required information.

To improve the quality of learning, increase the effectiveness of the duration and source of energy for schools, both in 
guiding practice activities or school administration, such as in working on report cards, the use of information technology is highly desirable. In collecting, calculating student grades, and printing student report cards, this report card processing information system will greatly facilitate the process of making student report cards.

\section{RESEARCH METHODS}

\section{A. Information Systems}

An information system is a system that is produced by people who are divided into parts into a body to achieve the goal of presenting data [1].

\section{B. Data processing}

An information system is a system that is produced by people who are divided into parts into a body to achieve the goal of presenting data [2].

\section{Website}

Website or short for the web can be known as a group of pages that are divided into several pages that contain data in the form of virtual information in the form of text, paintings, films, audio, and other animations that are carried out via connection routes [3].

\section{Report Card}

Report cards are information on the results of teaching participants' information while exploring teaching and learning activities and submitted at the end of the activity twice a year whose reporting, in this case, is the results of daily quizzes, daily obligations, midterm tests, end-of-semester tests, character, extracurricular along with the required records related to reporting cards [4].

\section{E. Student}

Students or students are those who are specially handed over by their parents to explore training activities held at the school, which aim to become a creature who has insight, skills, professionalism, character, has high morals, and is independent [5].

\section{F. Teacher}

The teacher or teacher is a person who guides and provides teaching because of his rights and obligations he is responsible for the learning of teaching participants [6].

\section{G. School Administration}

School administration is a sub-system of the body, in this case, it is a school body. The key activity is to take care of all forms of school administration, from correspondence to record keeping. So the rules of effort are not only related to correspondence activities but also relate to all explanatory materials and data in the form of scripts [7].

\section{H. Anfield Modeling Language (UML)}

UML (Unified Modeling Language) is a description that is widely used in industry to describe requirements, make system analysis and design, and describe systems in objectoriented programming [8]. The following are the types of UML:

\section{Use Case Diagram}

Use Case Diagram is a model for data system actions to be made. Use case charts can be used to identify the uses of everything contained in the data system and who has the power to use those uses [9].

2. Class Diagram

The class chart describes the state of the system usability and requirements related to important menus and database connections [10].

\section{Activity Diagram}

Activity diagrams describe a workflow (activity movement) or activity (activity) of a system or business field [9].

4. Sequence Diagram

Sequence diagrams describe the subject's actions against a use case by defining the duration of the subject's life and the notes to be sent and obtained by fellow-subjects [9].

\section{MySQL}

MySQL is a relational database management system. That is information that is managed through a database that will be placed in several separate tables so that dealing with information will be much faster. MySQL can also be used to manage databases from the smallest to the largest[11].

\section{J. Database}

A database is a collection of interrelated information, hidden in external funds and used as special software to manipulate it. The database is also a significant part of the information system because it acts as a data facilitator for its users [12].

\section{K. Waterfal}

The modified waterfall form is a sequential concept method, often used in software development methods, in its progress, it always flows to the bottom (like a waterfall) through the levels of communication, planning, modeling, construction, and deployment [13].

\section{PHP}

PHP is a scripting programming language that was originally developed to generate HTML statements. Moreover, programming developed with PHP one hundred percent is always shown in the form of HTML code [14]

\section{CodeIgniter}

Code Igniter is a framework from PHP that is opensource using the MVC (Visual Meteorological Condition) procedure to make it easier for developers or programmers to create an application with a website platform without having to make it from scratch[1].

\section{N. Black Box Testing}

Black Box Testing is centered on a functional element of the software. The tester can interpret the combination of an input situation and carry out tests on elements of a functional program. Black Box Testing is not an alternative solution to White Box Testing, however, an accessory for testing situations that are not covered by White Box Testing[15].

\section{RESULTS AND DISCUSSION}

To get an analysis of user needs for the system, Likert scale usability is needed as a method to be able to analyze user needs in using this system, the following steps are:

1. The Likert Scale Usability Test focuses on the convenience of consumers in using the student report card data system, as a result, the instrument used for this research is usability research. In the usability aspect, the test uses an evaluation sheet in the form of a questionnaire or questionnaire which will be distributed to respondents directly after trying the information system. The questionnaire used is the USE Questionnaire by Lund A.M (2001) which already has four criteria, namely usefulness, ease of learning, and satisfaction. In the calculation process, 
the questionnaire has five scales that are used as benchmarks, including strongly agree (SS), agree (S), uncertain (RG), disagree (TS), and strongly disagree (STS). The following is a table of Likert scale usability questions:

Table 1 Questionnaire Likert Scale
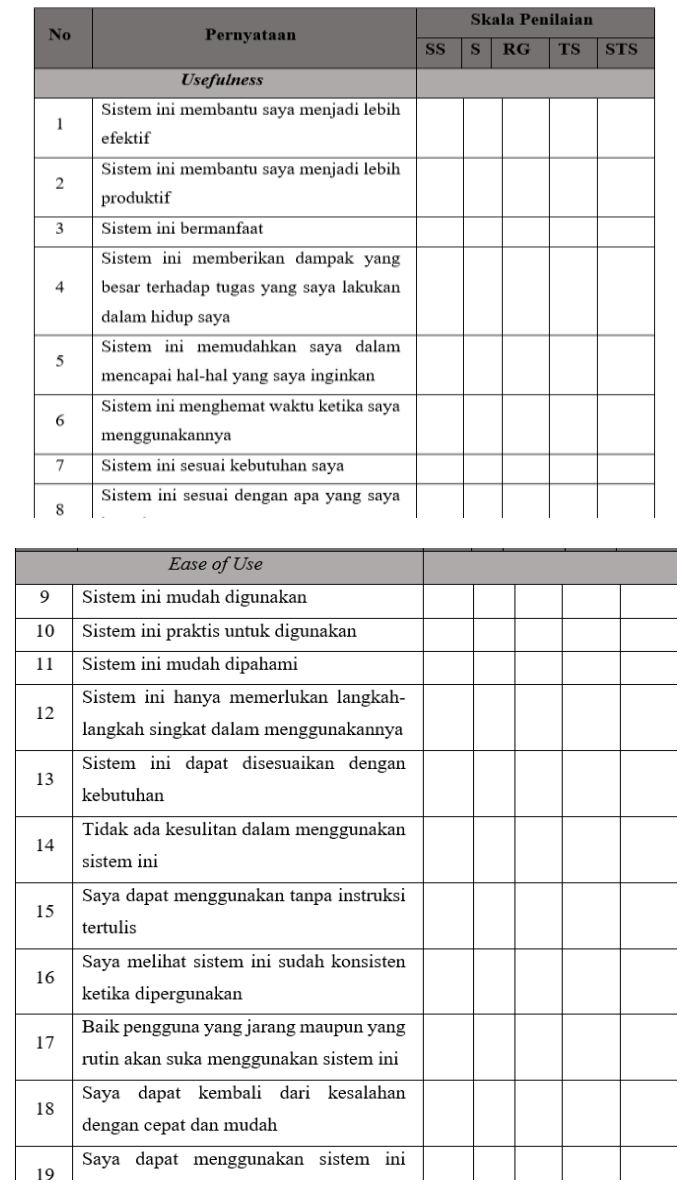

\begin{tabular}{|l|l|l|l|l|l|l|}
\hline \multicolumn{2}{|c|}{ Ease of Learning } & \multicolumn{2}{|l|}{} \\
\hline 20 & $\begin{array}{l}\text { Saya belajar menggunakan sistem ini } \\
\text { dengan cepat }\end{array}$ & & & & & \\
\hline 21 & $\begin{array}{l}\text { Saya mengingat penggunaan sistem ini } \\
\text { dengan mudah }\end{array}$ & & & & & \\
\hline 22 & Penggunaan sistem ini mudah dipelajari & & & & & \\
\hline 23 & $\begin{array}{l}\text { Saya mahir menggunakan sistem ini } \\
\text { dengan cepat }\end{array}$ & & & & \\
\hline
\end{tabular}

\begin{tabular}{|c|l|l|l|l|l|l}
\hline \multicolumn{2}{|c|}{ Satisfaction } & \multicolumn{3}{|l|}{} \\
\hline 24 & Saya puas dengan sistem ini & & & & & \\
\hline 25 & $\begin{array}{l}\text { Saya akan merekomendasikan aplikasi } \\
\text { ini kepada teman }\end{array}$ & & & & & \\
\hline 26 & $\begin{array}{l}\text { Aplikasi ini menyenangkan untuk } \\
\text { digunakan }\end{array}$ & & & & & \\
\hline 27 & $\begin{array}{l}\text { Aplikasi ini bekerja seperti yang saya } \\
\text { inginkan }\end{array}$ & & & & & \\
\hline 28 & Aplikasi ini sangat bagus & & & & & \\
\hline 29 & $\begin{array}{l}\text { Saya merasa saya harus memiliki aplikasi } \\
\text { ini }\end{array}$ & & & & & \\
\hline 30 & Anlikasi ini nvaman untuk diønakan & & & & & \\
\hline
\end{tabular}

2. Data analysis techniques are used to determine the level of achievement of the objectives of the research based on the data that has been collected. Testing this usability aspect by using Likert scale quantitative data analysis. The Likert scale contained in the USE Questionnaire instrument can use answers on a scale of five or scale seven, in this study using a scale of five. According to Sugiyono (2009), the answers to each instrument using a
Likert scale have a gradation from very positive to negative. The value of 1 is the smallest while the value of 5 is the largest.

Table 2 Likert Skala Scale Classification

\begin{tabular}{|c|l|c|}
\hline No & \multicolumn{1}{|c|}{ Kategori } & Nilai \\
\hline 1 & Sangat Setuju (SS) & 5 \\
\hline 2 & Setuju (S) & 4 \\
\hline 3 & Ragu-Ragu (RG) & 3 \\
\hline 4 & Tidak Setuju (TS) & 2 \\
\hline 5 & Sangat tidak Setuju (STS) & 1 \\
\hline
\end{tabular}

the total value obtained is then calculated by the

following formula.

persentase $(\%)=$ total value

Maximal value

Information :

Total value $=$ total value obtained from respondents' answers

Maximum value $=$ number of statements $\mathrm{x}$ number of respondents $\mathrm{x} 5$

After getting the results of the calculations, the values obtained will then be converted into qualitative values in the percentage assessment table. Before knowing the percentage assessment table first, look for the interval distance rating of the Likert scale using the following formula.

Interval $=100 /$ Total Score $($ Likert $)$

$=100 / 5$

$=20$

From the calculation of the interval above, it can be seen that the result of the distance interval for the assessment percentage table is 20 , so the percentage assessment table can be seen in Table 3 .

Table 3 rating percentage

\begin{tabular}{|c|l|l|}
\hline No & Persentase pencapaian & \multicolumn{1}{|c|}{ Interpretasi } \\
\hline 1 & $0 \%-19,99 \%$ & Sangat Tidak Baik \\
\hline 2 & $20 \%-39,99 \%$ & Kurang Baik \\
\hline 3 & $40 \%-59,99 \%$ & Cukup \\
\hline 4 & $60 \%-79,99 \%$ & Baik \\
\hline 5 & $80 \%-100 \%$ & Sangat Baik
\end{tabular}

3. Furthermore, the results of testing data from the four tables are collected and accumulated so that it will produce a summary of the usability testing of the student report card processing information system with a total score that can be seen in the following table.

Table 4 Results of Usability Test Accumulated Data 


\begin{tabular}{|c|l|c|c|c|c|c|c|}
\hline No & \multicolumn{1}{|c|}{ Nama Reponden } & $\begin{array}{c}\text { Useful- } \\
\text { ness }\end{array}$ & $\begin{array}{c}\text { Ease of } \\
\text { Use }\end{array}$ & $\begin{array}{c}\text { Ease of } \\
\text { Learning }\end{array}$ & $\begin{array}{c}\text { Satisfa- } \\
\text { ction }\end{array}$ & $\begin{array}{c}\text { Skor } \\
\text { Total }\end{array}$ & $\begin{array}{c}\text { Skor } \\
\text { Mak }\end{array}$ \\
\hline 1 & Triwi Purbandari & 37 & 48 & 17 & 32 & 134 & 150 \\
\hline 2 & M. Reza Primadi, M.Pd & 37 & 50 & 18 & 33 & 138 & 150 \\
\hline 3 & Tuti Lestari & 32 & 39 & 14 & 28 & 113 & 150 \\
\hline 4 & Satria Aji S.Kom & 40 & 43 & 15 & 24 & 122 & 150 \\
\hline 5 & Eko Prasetyo & 35 & 44 & 16 & 29 & 124 & 150 \\
\hline 6 & Eko Febriyanto & 33 & 44 & 16 & 28 & 121 & 150 \\
\hline 7 & HimatulMuniroh, S.Pd & 32 & 44 & 16 & 28 & 120 & 150 \\
\hline 8 & Sumanto, A.Md & 32 & 43 & 16 & 28 & 119 & 150 \\
\hline 9 & Budi Prasetyo & 31 & 43 & 16 & 28 & 118 & 150 \\
\hline 10 & Neni Supiyanti & 36 & 45 & 18 & 30 & 129 & 150 \\
\hline 11 & $\begin{array}{l}\text { Dra. Inuk Inggit } \\
\text { Merdekawati }\end{array}$ & 32 & 47 & 16 & 32 & 127 & 150 \\
\hline 12 & Drs. Fadlan & 33 & 45 & 17 & 29 & 124 & 150 \\
\hline 13 & Nurningsih, S.Ag & 35 & 44 & 16 & 34 & 129 & 150 \\
\hline 14 & Susi Hartini, S.Pd & 30 & 40 & 16 & 28 & 114 & 150 \\
\hline 15 & Siti Khotijah & 37 & 49 & 17 & 30 & 133 & 150 \\
\hline 16 & Estri Wryani & 38 & 54 & 20 & 34 & 146 & 150 \\
\hline 17 & Mimin Sukaesih, S.Pd & 35 & 46 & 18 & 32 & 131 & 150 \\
\hline 18 & Maryanto, S.Pd & 35 & 47 & 18 & 32 & 132 & 150 \\
\hline 19 & Dra. Shoimah & 37 & 47 & 16 & 29 & 129 & 150 \\
\hline 20 & Wahyu Sanjaya & 38 & 48 & 17 & 32 & 135 & 150 \\
\hline Jumlah & & & & & 2538 & 3006 \\
\hline & & & & & & & \\
\hline
\end{tabular}

Based on the results of the accumulated usability test data in Table 4.33, a total score of 2538 points was obtained from a maximum possible score of 3000 points. From the results obtained, the percentage of eligibility is calculated based on the data obtained. The calculation of the percentage of eligibility based on the data is as follows.

$$
\begin{aligned}
& (\%)=\frac{\text { Total Score }}{\text { Maximal Scorel }} \times 100 \% \\
& =\frac{2538}{3000} \times 100 \% \\
& =84.6 \%
\end{aligned}
$$

The result of calculating the percentage of eligibility is $84.6 \%$ so it can be concluded that the student report card processing information system meets the usability standard with the "very good" category when viewed in the feasibility percentage table contained in CHAPTER 3. A usability test is a test used in beta testing is a stage last in the construction process. With input and suggestions, the student report card processing information system will continue to be developed based on user evaluations so that this student report card processing information system can achieve the maximum level of feasibility.

After getting the results of the Likert scale usability testing related to data requirements to determine the level of user interest, the next stage is the development and design of the system following the stages in making the system:

1. In designing this system using a Use Case Diagram as a modeling system, which was created using UML (Unified Modeling Language). describe in building a system program. It is used as a medium that has a function to design the system and describe the interaction between the actor and the system. The following is an example of a System Diagram Use Case design:

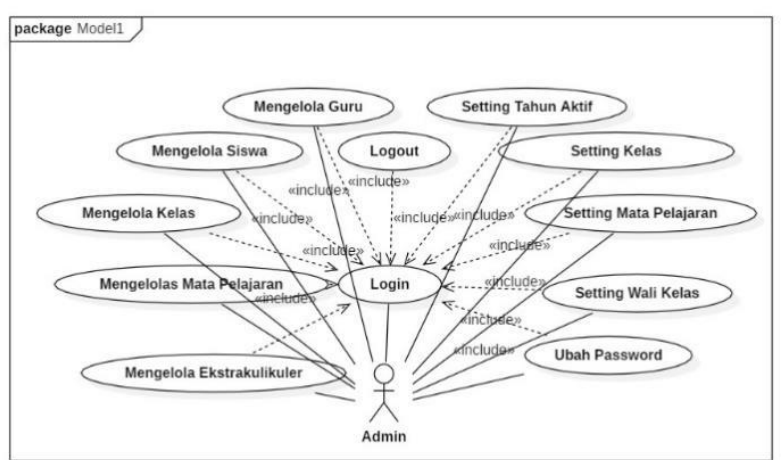

Figure 1 Use Case Diagram

2. Activity diagram of system capital is useful in describing the workflow on the system such as describing login activities, data management activities, modifying data, and deleting data. The following is an example of an activity diagram that has been created.

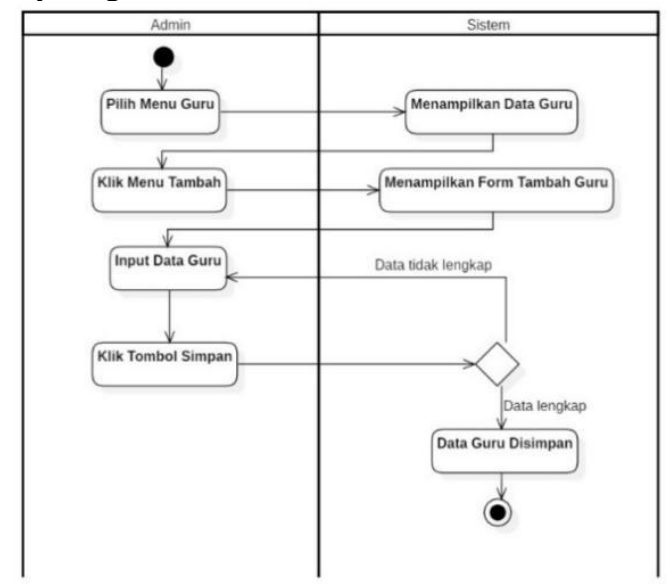

Figure 2 Activity Diagram

3. Squance Diagrams are useful for compiling the steps of messages sent to find out the flow of the relationship between objects because the sequence is the most useful diagram for dividing the use case model into a Barangin system specification. The following Squance Example Diagram for designing a Goods Lending System can be seen below.

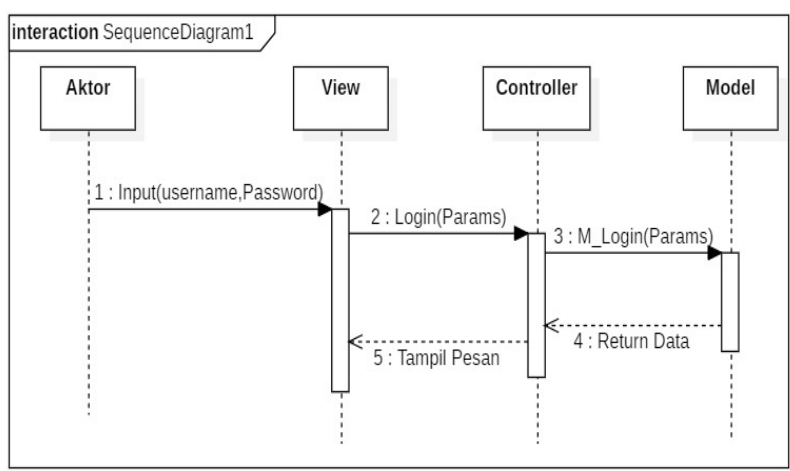

Figure 3 Sequence Diagram

4. A class Diagram is a modeling of the system design structure contained in the database. Class Diagram also aims to describe the functions needed in designing and creating systems. The following is an example of a Class Diagram for designing a Goods Lending System, which can be seen below: 


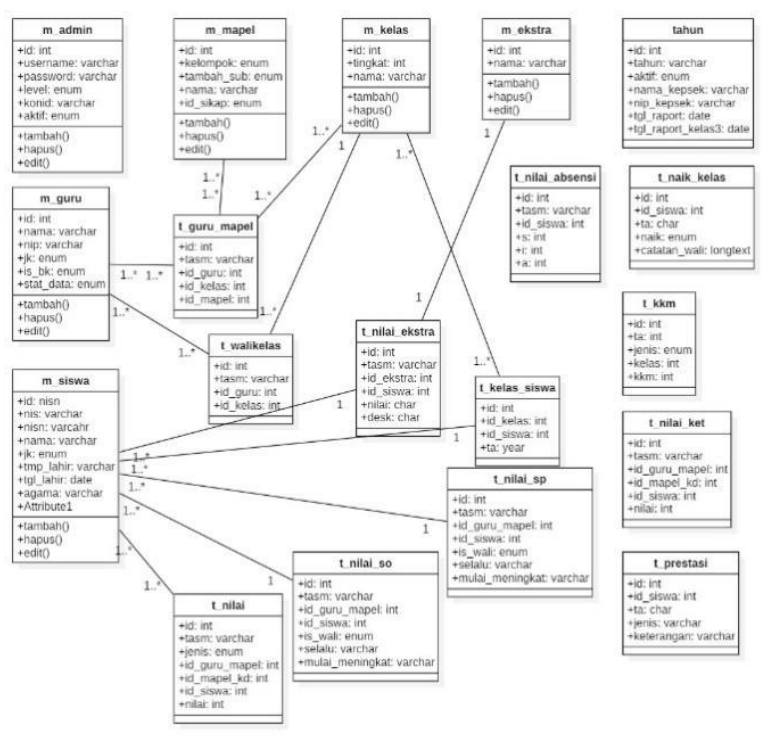

Figure 4 Class Diagram

5. System Interface Design

In designing this User Interface, it is designed using a pencil application. User interface design aims to describe the appearance of the system to be created. the following is the user interface design of the Goods Asset Inventory System:

- Login Interface Design

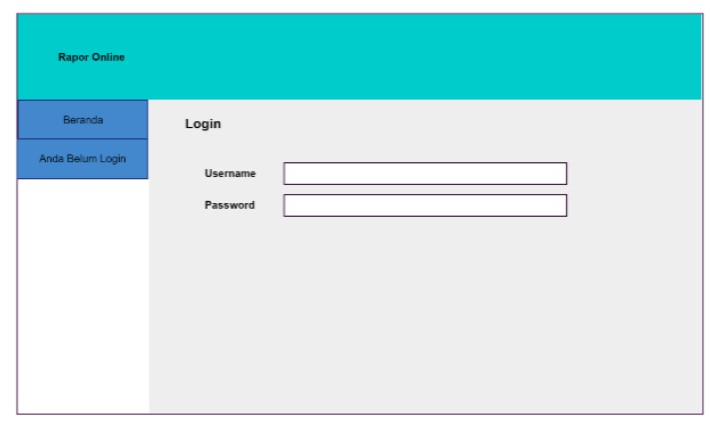

Figure 5 Login Interface Design

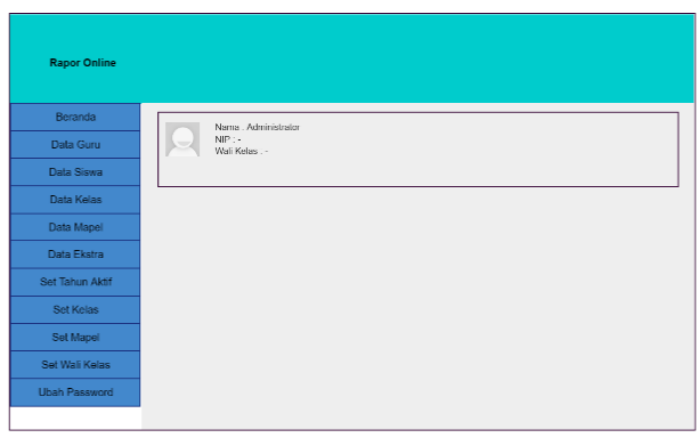

Figure 6 Admin Interface Design

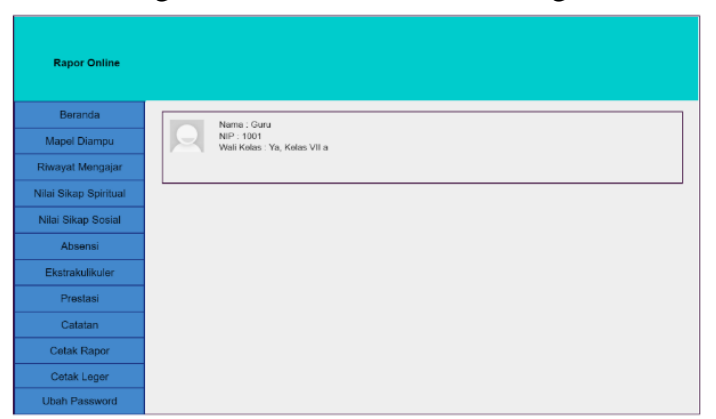

Figure 7 Teacher Interface Design

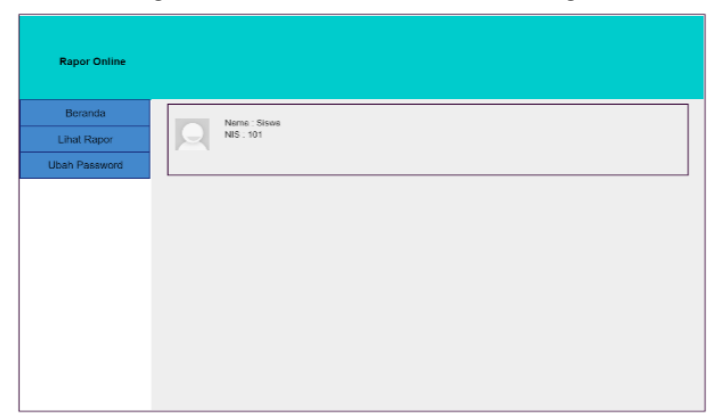

Figure 7 Student Interface Design

\section{CONCLUSION}

Based on the results of research and discussion, the following conclusions can be drawn:

1. 1. The student report card processing information system uses the waterfall development model from Pressman with the stages of communication, planning, modeling, construction, and deployment. The information system developed has features to manage teachers, manage students, manage classes, manage subjects, manage grades, and print student report cards.

2. The developed information system has carried out tests that focus on usability aspects with the calculation results in the very good category, the product is developed to facilitate the user's work so that the objectives of the research are achieved.

\section{REFERENCE}

[1] M. Destiningrum and Q. J. Adrian, "Sistem Informasi Penjadwalan Dokter Berbassis Web Dengan Menggunakan Framework Codeigniter (Studi Kasus: Rumah Sakit Yukum Medical Centre)," J. Teknoinfo, vol. 11, no. 2, p. 30, 2017, doi: 10.33365/jti.v11i2.24.

[2] M. H. A. Muhdar Abdurahman1, Mudar Safi2, "IJIS Indonesian Journal on Information System ISSN 25486438," IJIS-Indonesia J. Inf. Syst., vol. 4, no. April, pp. 69-76, 2019, [Online]. Available: https://media.neliti.com/media/publications/260171sistem-informasi-pengolahan-data-pembelie5ea5a2b.pdf.

[3] A. Josi, "Penerapan Metode Prototyping Dalam Membangun Website Desa (Studi Kasus Desa Sugihan Kecamatan Rambang)," Jti, vol. 9, no. 1, pp. 50-57, 2017.

[4] A. HELMY SYAHRIZAL, "Strategi Optimalisasi Pengelolaan Kekayaan (Aset) Desa Dalam Pembangunan Desa (Studi Kasus Di Desa Sambiroto Kecamatan Kapas Kabupaten Bojonegoro)," Publika, vol. 6, no. 4, 2018.

[5] E. R. dan E. Yuliawati, "Pengembangan Produk Lampu Meja Belajar dengan Metode Kano dan Quality Function Deployment (QFD)," J. Res. Technol., vol. 2, no. 2, pp. 78-86, 2016.

[6] N. M. Janna, "Konsep Uji Validitas dan Reliabilitas dengan Menggunakan SPSS," Artik. Sekol. Tinggi Agama Islam Darul Dakwah Wal-Irsyad Kota Makassar, no. 18210047, pp. 1-13, 2020.

[7] E. SANTIKA, "Pengertian dan proses administrasi ketatausahaan sekolah," no. 18029105, pp. 1-5, 2020, 
doi: $10.31227 /$ osf.io/3q4xm.

[8] D. Susianto, "Perancangan Sistem Pemesanan E-Tiket Pada Wisata Di Lampung Berbasis Web Mobil," vol. 2, pp. 60-71, 2019.

[9] K. Kawano, Y. Umemura, and Y. Kano, " Field Assessment and Inheritance of Cassava Resistance to Superelongation Disease 1," Crop Sci., vol. 23, no. 2, pp. 201-205, 1983, DOI: 10.2135/cropsci1983.0011183x002300020002x.

[10] B. Huda, "Sistem Informasi Data Penduduk Berbasis Android Dan Web Monitoring Studi Kasus Pemerintah Kota Karawang (Penelitian dilakukan di Kab. Karawang)," Buana Ilmu, vol. 3, no. 1, pp. 62-69, 2018, doi: $10.36805 /$ bi.v3i1.456.

[11] D. Sanjaya, H. Abdurachman, A. A. Wicaksono, and F. Masya, "Sistem Informasi Pengendalian Asset Kendaraan Di Perusahaan Transportasi," Rabit J. Teknol. dan Sist. Inf. Univrab, vol. 6, no. 1, pp. 24-32, 2021, doi: 10.36341/rabit.v6i1.1544.

[12] A. Andaru, "Pengertian database secara umum," $O S F$ Prepr., p. 2, 2018.

[13] H. Kurniawan, W. Apriliah, I. Kurnia, and D. Firmansyah, "Penerapan Metode Waterfall Dalam Perancangan Sistem Informasi Penggajian Pada Smk Bina Karya Karawang," J. Interkom J. Publ. Ilm. Bid. Teknol. Inf. dan Komun., vol. 14, no. 4, pp. 13-23, 2021, doi: 10.35969/interkom.v14i4.78.

[14] N. N. Abdur Rochman,Achmad Sidik, "Perancangan Sistem Informasi Administrasi Pembayaran SPP Siswa Berbasis Web di SMK Al-Amanah," J. Sisfotek Glob., vol. 8, no. 1, pp. 52-52, 2018.

[15] Q. Mardzotillah and M. Ridwan, "Sistem Tracer Study Dan Persebaran Alumni Berbasis Web Di Universitas Islam Syekh-Yusuf Tangerang," Jutis (Jurnal Tek. Inform., vol. 8, no. 1, pp. 90-106, 2020, [Online]. Available:

http://ejournal.unis.ac.id/index.php/jutis/article/view/70 5. 